\title{
PRZEMOC W WYCHOWANIU... W POLSKIM WYDANIU. POSTAWY RODZICÓW WOBEC KAR CIELESNYCH
}

\begin{abstract}
Jarosz Ewa, Przemoc w wychowaniu... w polskim wydaniu. Postawy rodziców wobec kar cielesnych [Violence in Upbringing in Polish Edition. Parents' Attitudes Towards Corporal Punishment]. Studia Edukacyjne nr 47, 2018, Poznań 2018, pp. 113-135 Adam Mickiewicz University Press. ISSN 1233-6688. DOI: $10.14746 /$ se.2018.47.8
\end{abstract}

The worldwide discourse on the problem of corporal punishment presents the discussion and results of research that gives the evidence of serious harm that $\mathrm{CP}$ does. In this light the need of intensive efforts to eliminate corporal punishment as the most frequent form of violence against children is strongly emphasized in the last years. Among different activities dedicated to stop the problem research on various indicators correlated with the use of corporal punishment are recommended. One of them is social acceptance of violent behaviors in relationship with a child. Due to this recommendations also in Poland proper research has been done in order to get a diagnosis of social attitudes towards corporal punishment. This paper presents some results of the research of the year 2017 commissioned by the Ombudsman for Children, which was the $7^{\text {th }}$ edition of the monitoring of social attitudes on violence in upbringing that has been continued since 2011. The below presentations focuses on results of parents as a group of the general population. Additionally parents were asked also about their own behaviors towards their children, as an attempt not to assess directly the range of the use of corporal punishment by them but to get the picture of the another face of their attitudes toward the problem. In the face of the results it can be said that the picture of parents' approval of violence in upbringing must be regarded as problematic and needing determined interventions. The most problematic is the level of the acceptance of these behaviors, which often are not clearly named in a public space as violence like spanking. The level of the approval of violence toward children among Polish parents should be regarded as a negative context of child well-being in Poland which definitely conduces to the existence of violent behaviors in everyday rising practices and the harm experienced by children.

Key words: corporal punishment, violence against children, parents' attitudes on corporal punishment

\section{Wprowadzenie. Kary cielesne - znaczenie indywidualne i społeczne problemu}

Dewastujący wpływ doświadczania przemocy w dzieciństwie jest obecnie dość powszechnie uznawany. W ostatnich latach badacze silnie akcen- 
tują jednak szkodliwość także określanych łagodniejszych jej postaci, czyli stosowania kar cielesnych, w tym tak zwanych klapsów. Pojawiło się sporo publikacji, które ukazują poważne negatywne skutki rozwojowe takich doświadczeń. Destrukcyjny wpływ stosowania kar cielesnych wobec dzieci, a zwłaszcza tak zwanych lżejszych ich postaci, czyli kolokwialnie mówiąc klapsów, jest zwykle społecznie kontestowany. Nazywanie kar cielesnych przemocą i dostrzeganie $\mathrm{w}$ nich jakiegoś zagrożenia dla rozwoju dziecka jest $w$ wielu społeczeństwach traktowane jako wyolbrzymianie czy w ogóle kreowanie sztucznego problemu, którego w rzeczywistości nie ma. Tak jest i w Polsce, gdzie ponad połowa społeczeństwa aprobuje kary cielesne w postaci uderzania dziecka ${ }^{1}$, a prowadzone dyskusje, zarówno w wymiarze publicznym, jak i nierzadko, i co gorsza, w wymiarze profesjonalnym - wśród osób pracujących z dziećmi oraz te toczące się w skali prywatnej zwykle tę aprobatę cielesnego „upominania” dziecka wyrażają jeśli nie całkowicie, to z pewnymi zastrzeżeniami co do siły owego napominania i ewentualnie jej częstotliwości, nierzadko też z użyciem argumentów typu „byłem bity i wyrosłem na ludzi" czy "tyłek nie szklanka". Tymczasem, destrukcyjny wpływ kar cielesnych, a w tym samych klapsów, został w ostatnim czasie dość jednoznacznie wykazany w badaniach i obecnie jest mocno eksponowany w naukowo-badawczym dyskursie ${ }^{2}$ oraz w politycznych inicjatywach na rzecz eliminacji przemocy wobec dzieci ${ }^{3}$. Poprzez badania bezpośrednie oraz metaanalityczne wykazano bardzo wysokie prawdopodobieństwo wystąpienia u dzieci doznających kar cielesnych od rodziców szeregu negatywnych konsekwencji emocjonalnych, społecznych i zdrowotnych ${ }^{4}$. Co

${ }^{1}$ Zob. E. Jarosz, Przemoc w wychowaniu - czas z tym skończyć. Raport Rzecznika Praw Dziecka 2017, http://brpd.gov.pl/sites/default/files/przemoc_w_wychowaniu_raport_2017_0.pdf

2 E.T. Gershoff, Corporal punishment by parents and associated child behaviors and experiences: A meta-analytic and theoretical review, Psychological Bulletin, 2002, 128, s. 539-579; E.T. Gershoff $\mathrm{i}$ in., Parent Discipline Practices in an International Sample: Associations With Child Behaviors and Moderation by Perceived Normativeness, Child Development, 2010, 81, 2, s. 487-502; E.T. Gershoff $\mathrm{i}$ in., Changes in parents' spanking and reading as mechanisms for Head Start impacts on children, Journal of Family Psychology, 2016 Advance online publication, http://dx.doi.org/10.1037/ fam0000172; E.T. Gershoff, Spanking and child development: We know enough now to stop hitting our children, Child Development Perspectives, 2013, 7, s. 133-137, http://dx.doi.org/10.1111/ cdep.12038; E.T. Gershoff, A. Grogan-Kaylor, Spanking and Child Outcomes: Old Controversies and New Meta-Analyses, Journal of Family Psychology, 2016, s. 1-17.

${ }^{3}$ J.E. Durrant, R. Ensom, Physical punishment of children: Lessons from 20 years of research, Canadian Medical Association Journal, 2012, 184, s. 1373-1377.

${ }^{4}$ T.O. Afifi i in., Spanking and adult mental health impairment: The case for designation of spanking as an adverse childhood experience, Child Abuse and Neglect, 2017, 71, s. 24-31; E. Gershoff, A. Grogan-Kaylor, Spanking and Child Outcomes, s. 1-17; E.O. Paolucci, C. Violato, A meta-analysis of the published research on the affective, cognitive, and behavioral effects of corporal punishment, The Journal of Psychology, 2004, 138, s. 197-221, http:/ / dx.doi.org/10.3200/JRLP.138.3.197-222; R.E. Larzelere, B.R. Kuhn, Comparing child outcomes of physical punishment and alternative disci- 
istotne, niedawne opracowania wyraźnie podkreślają, że również klapsy, często przecież potocznie opatrywane określeniem „niewinne”, również owe poważne negatywne skutki rozwojowe powodują. Wśród określonych konsekwencji doznawania klapsów, przytaczane badania wskazują na wysokie prawdopodobieństwo rozwoju niskiej samooceny oraz problemów psychicznych i zachowaniowych, wysokie prawdopodobieństwo rozwoju postaw lękowych, pojawienia się skłonności do depresji, a nawet autoagresji i myśli samobójczych. Ponadto, wskazuje się w nich na nadużywanie substancji psychoaktywnych (alkoholu, leków) oraz skłonność do narkotyzowania się tych, którzy doświadczali klapsów. Badacze zwracają też uwagę na bardzo prawdopodobne wystąpienie zaburzeń poznawczych, w tym problemów z koncentracją uwagi oraz na obniżanie się możliwości intelektualnych dzieci doznających kar cielesnych. Te problemy, jak stwierdzono, są skutkiem w dużej mierze niekorzystnych zmian neurologicznych w mózgu, jakie odkryto u osób doświadczających kar fizycznych ${ }^{5}$. Stwierdzone zmiany w budowie i funkcjonowaniu mózgu wskutek doznawania kar cielesnych są, jak uważają eksperci, związane z całym szeregiem innych zaburzeń i problemów, jakie charakteryzują osoby z takimi doświadczeniami ${ }^{6}$. Przytoczone wcześniej różne badania wskazują na wysokie prawdopodobieństwo rozwoju zaburzeń eksternalizacyjnych oraz rozwój skłonności do stosowania agresji, a także zjawisko normalizowania stosowania przemocy przez dzieci wskutek doznawania kar cielesnych. W konsekwencji występuje proces wbudowywania przemocy $\mathrm{w}$ arsenał środków wykorzystywanych $\mathrm{w}$ relacjach $\mathrm{z}$ innymi, w tym także w kontekście późniejszych ról rodzicielskich ${ }^{7}$.

Zwolennicy kar cielesnych powtarzają uparcie jako argument, że są one skuteczne, że pomagają powstrzymywać dziecko od zachowań niepożąda-

plinary tactics: A metaanalysis, Clinical Child and Family Psychology Review, 2005, 8, s. 1-37, http:/ / dx.doi.org/10.1007/s10567-005-2340-z; C.J. Ferguson, Spanking, corporal punishment and negative longterm outcomes: A meta-analytic review of longitudinal studies, Clinical Psychology Review, 2013, 33, s. 196-208.

${ }^{5}$ Badacze jakkolwiek odkryli zmiany neurologiczne wskutek doświadczania kar cielesnych, wskazują, że przy dużej częstotliwości stosowania klapsów też mogą one wystąpić zob. A. Tomoda i in., Reduced Prefrontal Cortical Gray Matter Volume in Young Adults Exposed to Harsh Corporal Punishment, Neuroimage, 2009 Aug; 47(2), s. 66-71; M. Strauss, M.J. Paschall, Corporal Punishment by mothers and development of children's cognitive ability: a longitudinal stu$d y$ of two nationally representative age cohorts, Journal of Aggression, Maltreatment \& Trauma, 2009, 18(5) s. 459.

${ }^{6}$ Know Violence in Childhood, Ending Violence in Childhood. Global Report 2017. Know Violence in Childhood, New Delhi 2017, India; M. Teicher, Wounds that time won't heals. The neurobiology of child abuse, Cerebrum, 2000, 4, s. 50-67; D. Glaser, The effects of maltreatment on the developing brain, The Link, 2000, 16, 2.

7 T.O. Afifi i in., Spanking and adult mental health impairment; E. Gershoff, A. Grogan-Kaylor, Spanking and Child Outcomes. 
nych, że uczą dyscypliny. Wbrew jednak takim częstym obiegowym opiniom, badacze zgodnie podkreślają, że żadne badania nie pokazują owego dobroczynnego wpływu kar cielesnych, żadne nie wykazują ich wychowawczej efektywności. Wręcz przeciwnie, dowiedziono, iż wpływają one na zaburzenia procesu etyczno-społecznej internalizacji norm i zasad, że wpływają na rozwój zaburzenia samoregulacji i w efekcie wytwarzają tak zwaną zewnątrz-sterowność, czyli sprzyjają kształtowaniu osobowości działającej na zasadzie "kija i marchewki” 8 .

Patrząc na następstwa doświadczania przemocy, o których mówią eksperci, i rozważając je w kontekście rozmiarów występowania problemu kar cielesnych w perspektywie globalnej, a jak wskazuje się w światowych raportach, aż trzy czwarte globalnej populacji dzieci doświadcza przemocy w wychowaniu ${ }^{9}$, można uzmysłowić sobie dramatyzm sytuacji w kontekście kondycji populacji ludzi, tej obecnej i tej przyszłej.

W odwołaniu do poważnych następstw rozwojowych, jakie powoduje przemoc w wychowaniu, a z drugiej strony do idei praw człowieka, praw dziecka oraz konieczności ich poszanowania, na świecie podejmowane są liczne inicjatywy mające ochronić dzieci przed przemocą, $w$ tym tą codzienną występującą w ramach praktyk wychowawczych. Wśród nich istotną rolę pełnią reformy prawa zmierzające do zapewnienia pełnej ochrony legalistycznej dzieci przed wszelkimi formami przemocy - również karami cielesnymi. W chwili pisania tego tekstu 53 państwa na świecie wprowadziły już całkowity zakaz stosowania wszelkich form przemocy, a wiele innych podjęło proces legislacyjny zmierzający do uchwalenia takiego zakazu ${ }^{10}$. Polska wprowadziła stosowne regulacje zakazujące stosowania kar cielesnych w 2010 roku, na mocy ustawy nowelizującej Ustawę o przeciwdziałaniu przemocy w rodzinie. Ustawa ta wprowadziła do Kodeksu rodzinnego i opiekuńczego przepis „Osobom wykonującym władzę rodzicielską oraz sprawującym opiekę lub pieczę nad małoletnim zakazuje się stosowania kar cielesnych" (art. 96.1 krio). Reformy prawa oraz wprowadzanie prohibicji kar cielesnych jest jednak tylko jednym z kroków na drodze ich eliminacji. Obok reform prawnych postuluje się także różne inne działania zmierzające

8 T.O. Affifi i in., Spanking and adult mental health impairment.

${ }^{9}$ Know Violence in Childhood, Ending Violence in Childhood. Global Report 2017; Hidden in Plain sight. A statistical analysis of violence against children, UNICEF, New York September 2014; zob. też: Annual report of the Special Representative of the Secretary-General on Violence against Children, August 2017, http://srsg.violenceagainstchildren.org/http://www.srsg.un.org/ , A familiar face. Violence in the life of children and adolescents, UNICEF New York 2017.

${ }^{10}$ Bieżąca sytuacja dotycząca wprowadzania oficjalnego zakazu jest prezentowana przez The Global Initiative to End Corporal Punishment na stronie http:/ /www.endcorporalpunishment.org/ 
do faktycznej implementacji prawa zakazującego przemocy oraz do faktycznej eliminacji kar cielesnych ${ }^{11}$. W tym obszarze wymienia się jako skuteczne sposoby oddziaływania: edukację społeczną, rozwój pozytywnego rodzicielstwa poprzez edukację rodziców ${ }^{12}$, podnoszenie kompetencji odpowiednich służb i profesjonalistów, ale również prowadzenie rzetelnych i systematycznych badań nad zjawiskiem kar cielesnych ${ }^{13}$.

\section{Prowadzenie badań nad karami cielesnymi i ich społeczną akceptacją. Metodologia badań własnych}

Jednym $\mathrm{z}$ istotnych działań $\mathrm{w}$ ramach ochrony dzieci przed przemocą, działań dążących do eliminacji kar cielesnych, jest prowadzenie badań monitorujących występowanie zjawiska i jego konsekwencji oraz dotyczących jego uwarunkowań. Badania takie pozwalają między innymi analizować dynamikę zjawiska i jego „wrażliwość” na różne działania czy zjawiska społeczne, a czasami wprost pozwalają monitorować skuteczność podejmowanych programów i środków zmierzających do eliminacji wszelkich form przemocy doznawanej obecnie przez dzieci. Z tego powodu badania naukowe dotyczące problemu przemocy, w tym i kar cielesnych są zalecane przez ekspertów oraz przez polityczne rekomendacje wydawane na międzynarodowym gruncie. Wśród istotnych kierunków badań wskazuje się między innymi na te, które diagnozują i eksplorują postawy społeczne wobec kar cielesnych ${ }^{14}$. Przyjmuje się bowiem w świetle wielu badań nad uwarunkowaniami przemocy wobec dzieci ${ }^{15}$, iż kulturowy kontekst i społeczne przekonania na temat kar cielesnych oraz społeczno-kulturowa aprobata niektórych nawet tylko zachowań przemocy wobec dzieci należą do podstawowych czynników ryzyka występowania

${ }^{11}$ J. Durrant, i in., Parents' views of the relevance of a violence prevention program in high, medium, and low human development contexts, International Journal of Behavioral Development, 2017, 41(4), s. 523-531; K.D. Bussman, C. Erthal, A. Schroth, Effects of banning corporal punishment in Europe: A five-nation comparison, [w:] Global pathways to abolishing physical punishment: Realizing children's rights, Eds. J.E. Durrant, A.B. Smith, New York 2011, s. 299-286.

${ }^{12}$ Zob. np. tamże.

${ }^{13}$ Hidden in Plain sight. A statistical analysis of violence against children, UNICEF, New York September 2014.

${ }_{14}$ Towards a world free from violence. Global Survey on violence against children, New York 2013.

15 P.S. Pinheiro, World report on violence against children, UN, Lizbona 2006, www.violencestudy.int. 
problemu. Ten rodzaj badań jest więc od wielu lat realizowany w wielu krajach $^{16}$, także w naszym ${ }^{17}$.

Od 2011 roku prowadzony przeze mnie, na zlecenie Rzecznika Praw Dziecka, systematyczny monitoring postaw społecznych wobec przemocy w wychowaniu pokazuje poziom społecznej aprobaty dla różnych zachowań, które włączane są do kategorii „kary cielesne” oraz dynamikę postaw ${ }^{18}$. Co roku poddawana jest badaniom ogólnopolska reprezentatywna próba co najmniej 1000 osób powyżej 15. roku życia. Siódma edycja zrealizowana w 2017 roku objęła badaniami surveyowymi próbę 1042 Polaków powyżej 15. roku życia. Prowadzono je w pierwszych dniach września 2017 roku metodą wywiadów bezpośrednich (CAPI) przez firmę Kantar TNS w procedurze badania omnibusowego, według autorsko przygotowanego ciągu pytań (w większości dysjunktywnych).

Podobnie jak we wcześniejszych edycjach monitoringu postaw wobec przemocy $\mathrm{w}$ wychowaniu, celem badań $\mathrm{w} 2017$ roku było rozpoznanie poziomu społecznej aprobaty różnych zachowań przemocowych wobec dzieci oraz uznawania kar cielesnych za metody wychowawcze. $W$ badaniu poddano rozpoznaniu także wiedzę i nastawienie do prawa zakazującego stosowania przemocy. Celem było ponadto rozpoznanie społecznego nastawienia do interweniowania $\mathrm{w}$ sytuacje przemocy $\mathrm{w}$ wychowaniu $\mathrm{w}$ rodzinie. Ponadto, $\mathrm{w}$ perspektywie udziału $\mathrm{w}$ badaniach osób posiadających dzieci, $\mathrm{w}$ tym do 18. roku życia, starano się także rozpoznać poziom ujawnień na temat własnych zachowań przemocy wobec dzieci.

W poniższym opracowaniu proponuję przyjrzeć się analizie wyników uzyskanych w grupie rodziców posiadających dzieci do 18. roku życia. Były to 273 osoby, wśród których 51,3\% stanowiły kobiety, 50\% grupy - osoby w wieku 3039 lat. Bez wątpienia, grupa rodziców dzieci do 18. roku życia jest szczególnie

${ }^{16} \mathrm{~Np}$. E. Romano, T. Bell, R. Norian, Corporal punishment :examining Attitudes toward the law and factors influencing attitude change, Journal of Family violence, 2013, 28, s. 265-275; K.D. Bussman, C. Erthal, A. Schroth, Effects of banning corporal punishment in Europe.

17 Badania poza Rzecznikiem Praw Dziecka prowadzi np. Fundacja Dajemy Dzieciom Siłę (dawniej Dzieci Niczyje), a sporadycznie także ministerstwo odpowiedzialne za sprawy rodziny i sprawy socjalne.

${ }^{18}$ Wcześniejsze raporty dostępne są albo w postaci publikacji dzieci: E. Jarosz, Przemoc w wychowaniu. Między prawnym zakazem a społeczna akceptacja, Warszawa 2015; E. Jarosz, A. Nowak, Dzieci ofiary przemocy w rodzinie. Raport Rzecznika Praw Dziecka, Warszawa 2012, E. Jarosz, Polacy wobec bicia dzieci. Raport z badań 2013 dostępnych na stronie RPD, http:/ / brpd.gov. $\mathrm{pl} /$ ksiazki-informatory-poradniki/przemoc-w-wychowaniu-miedzy-prawnym-zakazem-spoleczna-akceptacja, http:// brpd.gov.pl/aktualnosci-ksiazki-informatory-poradniki/polacy-wobec-bicia-dzieci-raport-z-badan-2013 oraz http://brpd.gov.pl/ksiazki-informatory-poradniki/ dzieci-ofiary-przemocy-w-rodzinie-raport-rzecznika-praw-dziecka albo jako rozdziały w seryjnych publikacjach Informacja o działalności Rzecznika Praw dziecka z kolejnych lat 2012-2016, dostępnych na stronie http:/ / brpd.gov.pl/sprawozdania-z-dzialalnosci 
istotna z punktu widzenia aktualnej charakterystyki problemu kar cielesnych $\mathrm{i}$ ich aprobaty, a pośrednio stanowi także zasadniczą grupę odniesienia w szacowaniu aktualnego poziomu występowania problemu kar cielesnych.

\section{Aprobata zachowań przemocowych wobec dzieci przez rodziców}

W Polsce społeczna akceptacja zachowań przemocy wobec dzieci jest w sensie ogólnym niepokojąco wysoka, wyrażana przez wysoki odsetek społeczeństwa. Akceptację uderzania dziecka wykazało w 2017 roku 52\% badanych, a 27\% ujawniło pozytywny stosunek do tak zwanego lania ${ }^{19}$. We wszystkich analizowanych parametrach społecznej aprobaty wyniki uzyskane w grupie rodziców dzieci do 18. roku życia nie odbiegały znacząco od rozkładu w próbie ogólnej. Dane pokazują, iż niemal jedna czwarta rodziców aprobuje bicie dziecka, nie dostrzegając nic złego w sprawianiu dziecku lania (ryc. 1). Natomiast, zdecydowanych przeciwników takiego zachowania wobec dziecka jest wśród rodziców tylko nieco więcej niż jedna trzecia.

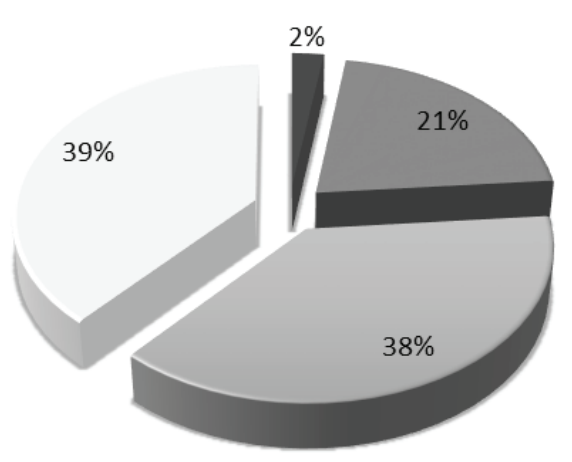

Ryc. 1. „Tak zwane lanie jeszcze nikomu specjalnie nie zaszkodziło" $(\mathrm{N}=273)$

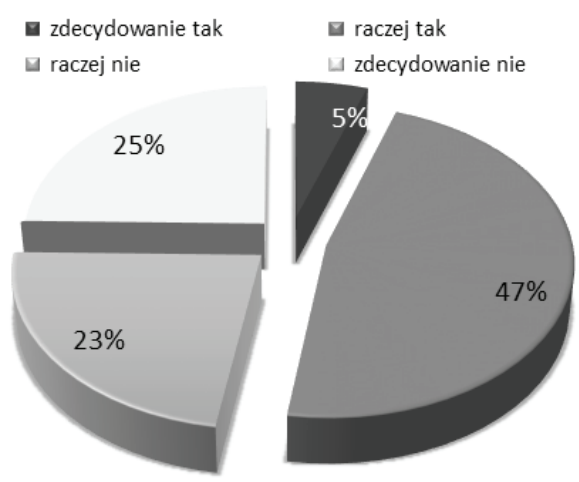

Ryc. 2. „Są takie sytuacje, kiedy trzeba dziecku dać klapsa" ( $\mathrm{N}=273)$

Jeszcze mniej korzystnie wypada sytuacja pod względem aprobaty rodziców dotyczącej uderzania dziecka, czyli wyrażając się kolokwialnie - klapsów (ryc. 2). To zachowanie przemocy aprobuje ponad połowa rodziców uważając, iż są sytuacje, kiedy dziecko należy uderzyć. Jeśli w rozkładzie danych

${ }^{19}$ Pełne dane dotyczące wskaźników uzyskanych w ogólnej próbie badawczej prezentuje raport „Przemoc w wychowaniu - czas z tym skończyć” umieszczony na stronie Rzecznika Praw Dziecka. 
skupić uwagę na grupie zdecydowanych przeciwników „klapsów”, to okaże się, iż jest nim jedynie co czwarty rodzic. Taki poziom akceptacji zachowań przemocy wobec dziecka przez rodziców jest z pewnością wysoce niepożądany w perspektywie oceny psychopedagogicznej i jednocześnie przedstawia smutny obraz na temat braku poszanowania praw dziecka. Jednocześnie jest też wskaźnikiem niewysokiej kultury pedagogicznej polskich rodziców. Na domiar złego, rodzice $\mathrm{w}$ niemałym odsetku aprobują także inne zachowania przemocy wobec dzieci (ryc. 3). Jakkolwiek w tym przypadku rozkład aprobaty jest zróżnicowany, to jednak równie niepokojący w ocenie psychopedagogicznej znaczenia takiej sytuacji.

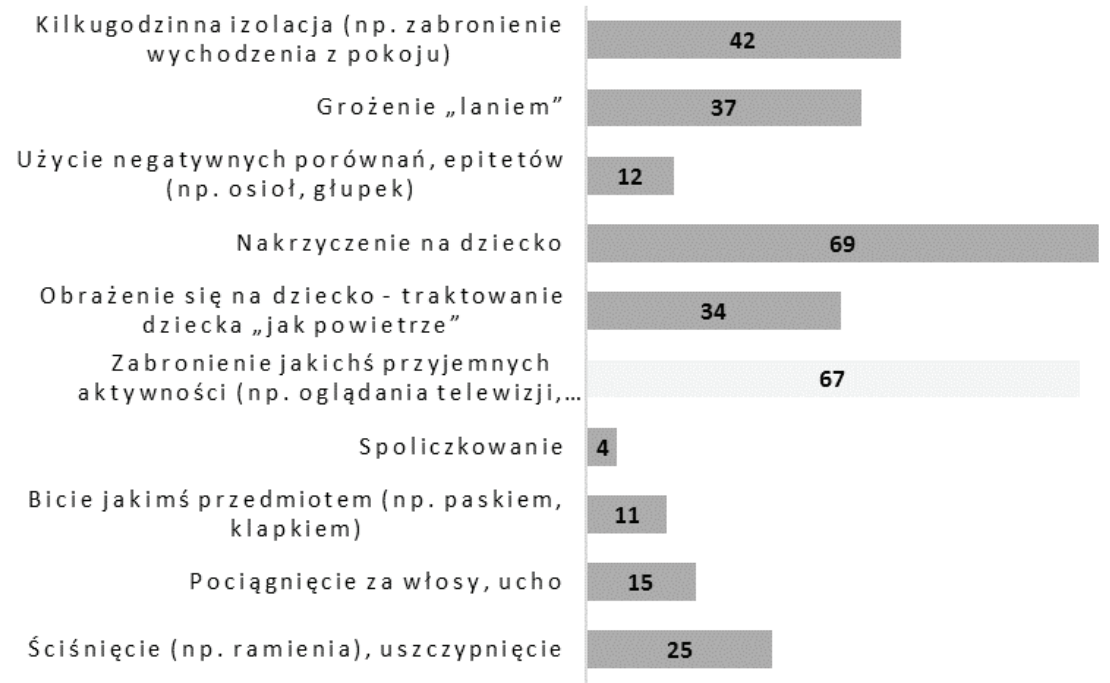

Ryc. 3. Które z wymienionych sposobów postępowania z dzieckiem mogą być Pana/Pani zdaniem wykorzystywane $\mathrm{w}$ wychowaniu $(\mathrm{N}=273)$

Wszystkie przedstawione w tym pytaniu do oceny badanym zachowania, poza "zabronieniem jakichś przyjemności”, to zachowania określane przez ekspertów jako przemocowe, mogące powodować negatywne konsekwencje, $\mathrm{w}$ tym poważne negatywne skutki emocjonalne $\mathrm{u}$ dziecka. Tymczasem, jak obrazuje to rozkład danych, niektóre z nich cieszą się stosunkowo wysoką aprobatą rodziców. Prym pod tym względem wiedzie krzyczenie na dziecko jako aprobowane przez dwie trzecie rodziców. Wysoki wskaźnik aprobaty uzyskały także wielogodzinna izolacja/zamknięcie dziecka w odosobnieniu, grożenie dziecku tak zwanym laniem, a także wrogie ignorowanie dziecka (traktowanie jak powietrze). Najmniejszą aprobatę uzyskało bicie przedmiotem oraz spoliczkowanie dziecka. Dane te pokazują, że najwyższa aprobata 
dotyczy tych zachowań wobec dziecka, które w potocznym rozumieniu nie są określane jako przemoc, natomiast najniższa - zachowań powszechnie rozumianych jako zachowania przemocy oraz zachowania uznawane za szczególnie poniżające.

Innym wymiarem aprobaty przez rodziców przemocy w wychowaniu jest uznawanie bicia za skuteczną metodę wychowawczą. Przy zastosowaniu bezpośredniego pytania, zebrane odpowiedzi wskazują, iż $17 \%$ rodziców wyraża taki pogląd, a sporo, bo aż $42 \%$, zdecydowanie przeciwstawia się takiemu podejściu (ryc. 4).

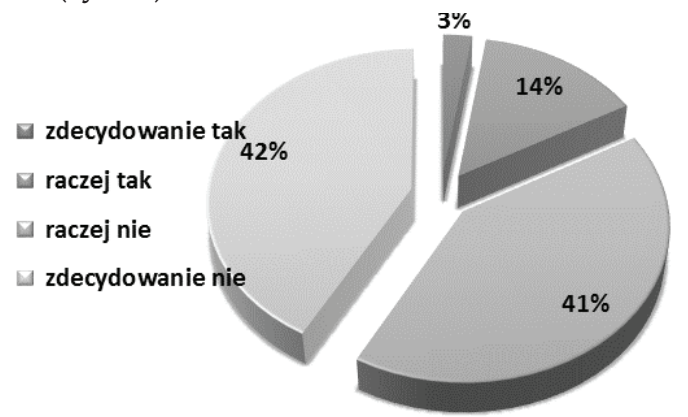

Ryc. 4. „Zbicie dziecka jest w niektórych sytuacjach najbardziej skuteczną metodą wychowawczą" ( $\mathrm{N}=273)$

Jeżeli jednak zapytać o tę samą kwestię w inny sposób, prezentując badanym trudne wychowawczo zachowania dziecka, to znaczy które $\mathrm{z}$ nich powodują, że dziecko zasługuje na karę cielesną, wówczas pojawiają się zdecydowanie pozytywne wskazania i w efekcie wartości procentowe (ryc. 5).

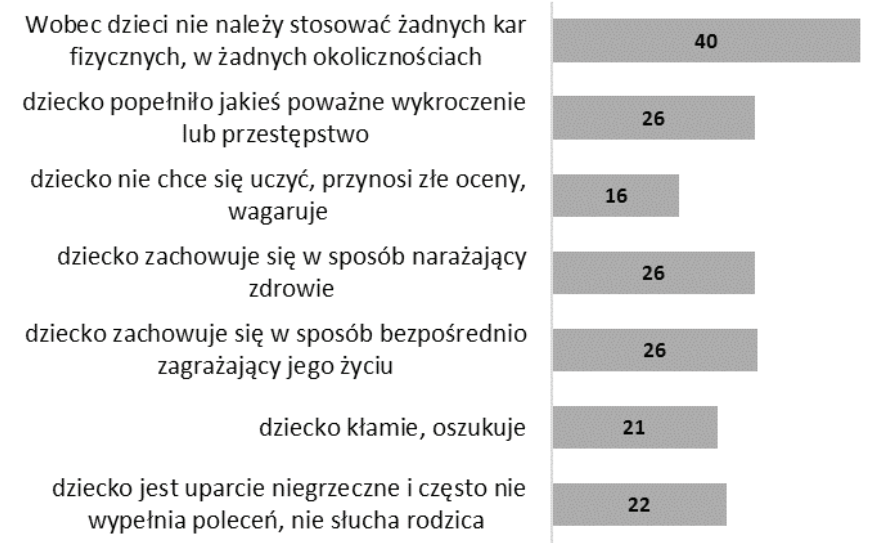

Ryc. 5. W jakich okolicznościach Pana/Pani zdaniem dziecko zasługuje na to, aby dostać w skórę $(\mathrm{N}=273)$ 
Warto przy okazji zwrócić uwagę, że kontekstem zachowań, które uzyskały najwyższą aprobatę zastosowania przemocy jest w zasadzie lęk rodzica o dziecko, czyli są to zachowania niosące niebezpieczeństwo zdrowia, życia lub pomyślnego rozwoju dziecka. Wskazała je ponad jedna czwarta rodziców. Nieco rzadziej kary cielesne są aprobowane w sytuacji nieposłuszeństwa dziecka i oszukiwania rodzica - około jedna piąta badanych. Tu z kolei kontekstem odbioru zachowania dziecka przez rodzica jest podważanie autorytetu rodzica. Najrzadziej aprobata stosowania kar cielesnych dotyczy sytuacji niepowodzeń szkolnych dziecka. Taki kierunek interpretacji tych wyników wydaje się uzasadniony także na tle ogólnych ustaleń dotyczących uwarunkowań zachowań przemocy wobec dzieci ze strony osób najbliższych, które wskazują na lęk oraz na niską samoocenę jako silne czynniki ryzyka posługiwania się wobec dziecka przemocą.

W obrazie uzyskanych odpowiedzi (ryc. 5) można także zwrócić uwagę na wielkość tej grupy rodziców (40\%), którzy zdeklarowali się jako całkowicie negujący stosowanie kar cielesnych w jakichkolwiek okolicznościach. Interpretacja tej wielkości w kategoriach optymistycznych czy negatywistycznych jest oczywiście względna. Pedagogiczny komentarz tej wielkości wydaje się raczej jednak nieoptymistyczny, gdyż oznacza, że $60 \%$ rodziców dopuszcza ewentualność „zasługiwania” przez dziecko na karę cielesną.

\section{Wykorzystywanie przemocy w wychowaniu w deklaracjach rodziców}

Przemoc stosowana przez rodziców w wychowaniu oraz ogólniej przemoc wobec dzieci jest zjawiskiem niezwykle trudnym pod względem trafności oszacowania zakresu jego występowania. W praktyce stosowane są różne sposoby i wskaźniki. Z jednej strony pokazuje się wskaźniki rzeczywiste (liczby bezwzględne) odnotowywanych w różnych statystykach przypadków przemocy wobec dzieci (statystyki tzw. incydentów - incidents). W Polsce przykładem takich statystyk są liczby małoletnich odnotowywanych w procedurze Niebieska Karta, jako ofiary przemocy domowej, czy statystyki wymiaru sprawiedliwości pokazujące liczby postępowań sądowych lub wyroków. Inny wymiar mają oszacowania rozmiarów zjawiska oparte na badaniach populacyjnych (survey), prowadzonych w grupach rodziców, dzieci oraz jako badania retrospekcyjne dorosłych. Obydwie strategie ukazywania zakresu problemu przemocy wobec dzieci mają swoje mocne i słabe strony, dlatego najczęściej są one wykorzystywane łącznie jako obrazujące występowanie zjawiska. 
W perspektywie badań populacyjnych, z jakimi mamy do czynienia w przypadku monitoringu Rzecznika Praw Dziecka, można opierać się tylko na deklaracjach rodziców co do prezentowania takich zachowań, czyli właściwie bazuje się na prawdomówności badanych i ich dobrej woli. $Z$ drugiej strony, biorąc pod uwagę przedmiot eksploracji, czyli prezentowanie zachowań przemocy w stosunku do dziecka jako obszar drażliwy w kontekście oceny społecznej, naznaczany częściowo negatywnie i działanie czynników ograniczających ową prawdomówność, wydaje się że uzyskane obrazy danych należy bardziej traktować $\mathrm{w}$ kategoriach poziomu przyznawania się rodziców do zachowań przemocy, niż ukazujące rzeczywisty poziom występowania przemocy w praktyce wychowawczej. Tym samym, odpowiedzi rodziców powinny być potraktowane jako swoisty wskaźnik ich postaw wobec przemocy w wychowaniu.

Badanym rodzicom oraz osobom posiadającym dzieci, w tym dorosłe, przedstawiono kilka pytań. Przy bezpośrednim zapytaniu o wykorzystanie tak zwanego lania, niewielu rodziców przyznało się do takiego zachowania (ryc. 6).

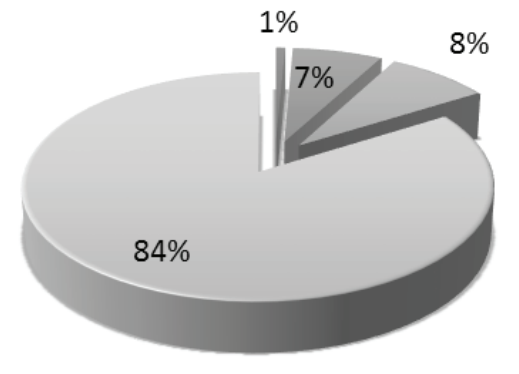

$\begin{array}{ll}\square \text { dosyć często } & \square \text { od czasu do czasu } \\ \square \text { raz lub kilka razy } & \square \text { nigdy }\end{array}$

Ryc. 6a. Czy zdarzyło się kiedykolwiek, że Pana/

Pani dziecko dostało tzw. lanie? $(\mathrm{N}=273)$

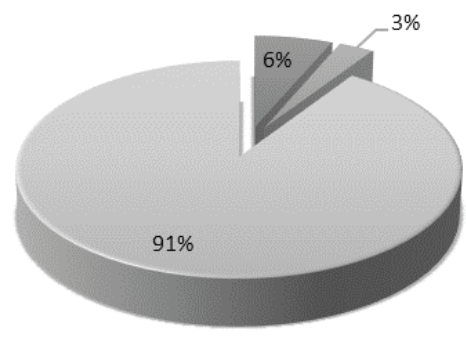

$\square$ od czasu do czasu $\square$ raz lub kilka razy $\square$ nigdy

Ryc. 6b. Czy w ciągu ostatniego roku zdarzyło się, że dziecko dostało tzw. lanie?

Jeszcze mniej - dwukrotnie mniej - przyznało się do zbicia dziecka $\mathrm{w}$ ostatnim czasie, to jest w ciągu ostatniego roku (ryc. 6b). Jak widać, rodzice dość rzadko przyznają się do zachowań ocenianych społecznie jednoznacznie jako przemoc wobec dzieci, choć i tak należy zwrócić uwagę, że wskaźniki kilkunastoprocentowe i niemal dziesięcioprocentowe nie są marginesowe. 
Nieco inaczej prezentuje się sytuacja odnośnie uderzania dziecka. W tym wypadku poziom ujawnień rodziców jest zdecydowanie wyższy (ryc. 7). Do zastosowania klapsów przyznało się aż 55\% rodziców, w tym co czwarty do jego zastosowania od czasu do czasu.

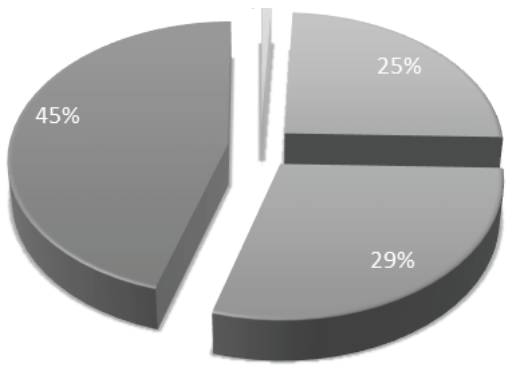

$\begin{array}{ll}\square \text { dosyć często } & \square \text { od czasu do czasu } \\ \square \text { raz lub kilka razy } & \square \text { nigdy }\end{array}$

Ryc. 7a. Czy zdarzyło się Panu/Pani kiedykolwiek wymierzyć swojemu dziecku klapsa?

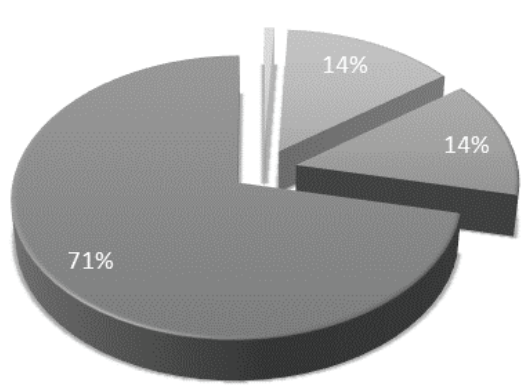

Ryc. 7b. Czy w ciągu ostatniego roku zdarzyło się Panu/Pani dać dziecku klapsa

Również w tej kwestii zdecydowanie rzadziej (niemal dwukrotnie) rodzice przyznawali się do wymierzania dziecku klapsa w ostatnim roku (ryc. 7b). Zarówno w przypadku tak zwanego lania, jak i wymierzania tak zwanych klapsów można by interpretować tę znaczącą różnicę ogólnego przyznania się oraz przyznania się do zachowania jako aktualnego ( $w$ ostatnim roku) optymistycznie - jako wskazującą na wycofywanie się rodziców z tego rodzaju zachowań z powodu zmiany postawy, albo jako związaną z dorastaniem dzieci badanych rodziców, gdyż stosowanie kar cielesnych, jak dowodzą badania, jest skorelowane z wiekiem dziecka, albo można też ją łączyć z mniejszą skłonnością (a większym oporem) do przyznawania się rodziców do obecnych zachowań w porównaniu z przeszłymi zachowaniami. Mniej bowiem czujemy się winni, jeśli nasze negatywne czyny dotyczą przeszłości niż są aktualne, toteż bardziej się do nich przyznajemy. Porównanie natomiast między sobą poziomu przyznawania rodziców do obu rodzajów zachowań sprawiania lania i klapsów - skłania do wniosku, iż rodzice chętniej ujawniają zachowania, które w sensie obyczajowo-kulturowym nie są jednoznacznie nazywane przemocą, czyli stosowanie klapsów. Ukazuje to też wyraźnie analiza dynamiki deklaracji rodziców na przestrzeni kilku lat (2014-2017), która pokazuje, że między obu zachowaniami istnieje wyraźna różnica w poziomie 
ujawnień rodziców (ryc. 8). Rodzice przyznają się do zachowań, których nie spostrzegają jako niewłaściwe, jako negatywnie społecznie oceniane.

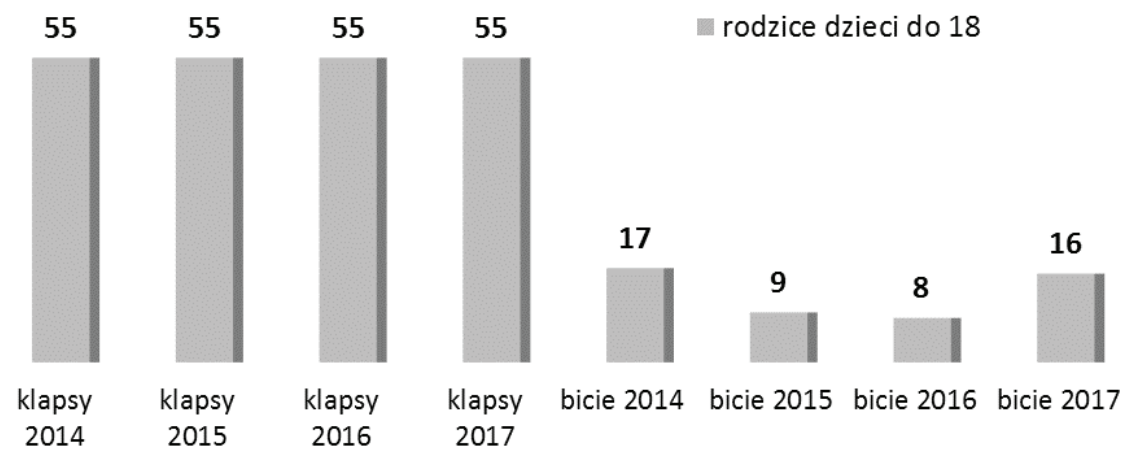

Ryc. 8. Dynamika ujawnień zachowań rodziców w latach 2014-2017

Tezę tę wzmacnia analiza korelacji odpowiedzi na pytania o stosowanie zachowań przemocy z wyrażanymi przez rodziców opiniami co do legalności prawnej tych zachowań. Na poziomie istotnym statystycznie $(0,05)$ do klapsów częściej przyznawali się rodzice, którzy uważali, iż bicie dziecka nie jest niezgodne z prawem. Przy okazji warto wskazać, iż do pozostałych cech modyfikujących stosowanie klapsów przez rodziców na poziomie istotnym statystycznie $(0,05)$ zaliczają się: własne doświadczenia przemocy w wychowaniu w dzieciństwie, niskie wykształcenie, starszy wiek rodziców oraz pochodzenie z małych miejscowości.

Rodzice pytani o inne zachowania przemocowe wobec własnych dzieci ujawniali na różnym poziomie - od kilku do kilkudziesięciu procent (ryc. 9). Do niektórych przyznawali się niemal powszechnie, podczas gdy inne wskazywane były przez nikły procent rodziców.

W obrazie wskazań można ponownie zauważyć, iż rodzice częściej przyznają się do zachowań nietraktowanych w wymiarze obyczajowo-kulturowym jako zachowania przemocowe wobec dziecka. Widać to w ujawnieniach do stosowania zachowań takich, jak "krzyczenie na dziecko”, do którego przyznała się większość badanych rodziców - 70\%, jak i w wysokości wskaźnika w kategorii „grożenie dziecku laniem” - 39\%. Z kolei, zachowania uznawane kulturowo za szczególnie poniżające (spoliczkowanie), czy ewidentnie traktowane społecznie jako przemoc fizyczna (bicie pasem) lub jako wyraz agresji werbalnej (wyzwiska) wskazywane były przez niewielki odsetek rodziców (10\% lub mniej). 


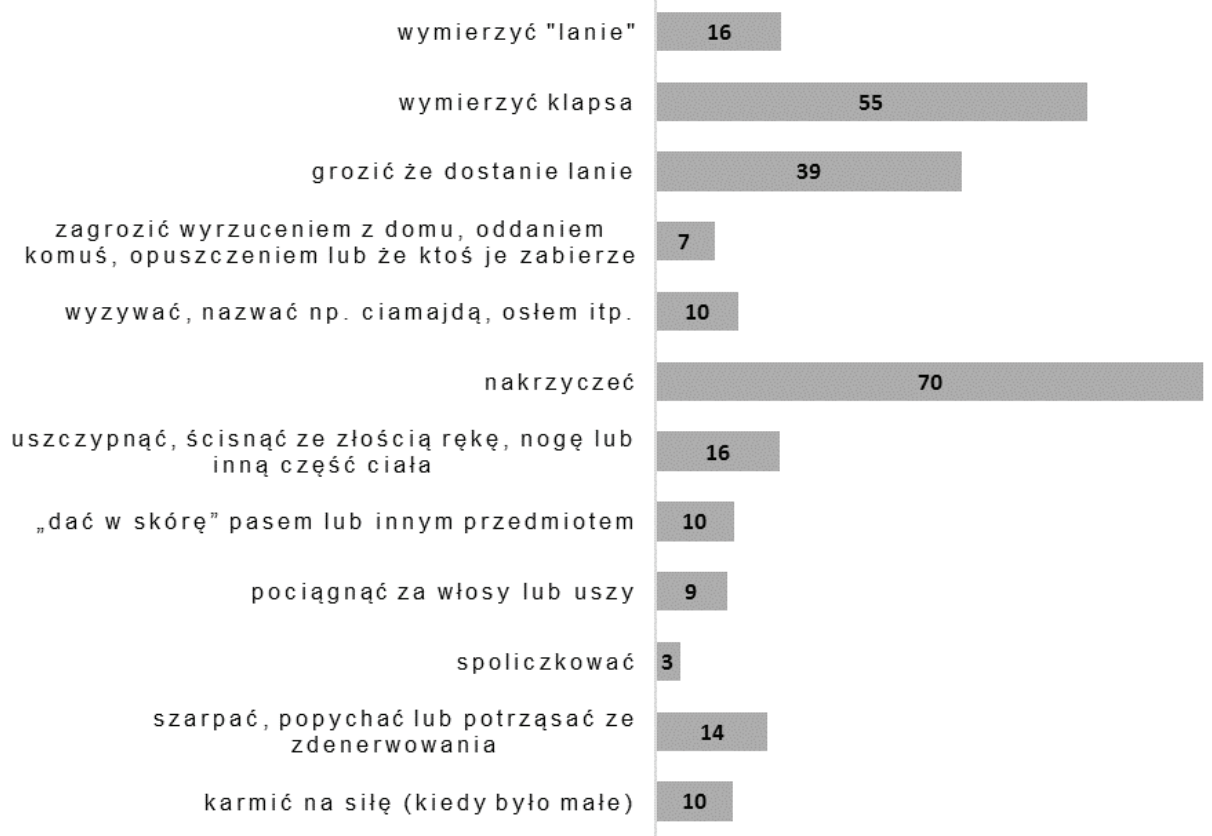

Ryc. 9. Dynamika ujawnień zachowań rodziców w latach 2014-2017

\section{Ocena działań podejmowanych wobec przemocy w wychowaniu}

W celu ukazania tego aspektu postaw rodziców wobec kwestii kar cielesnych, analizie poddano ich wiedzę o wprowadzonym w 2010 roku do Kodeksu rodzinnego i opiekuńczego zakazie stosowania kar cielesnych, a także zapytano o ocenę jego funkcjonalności. Ponadto, w obszarze analizy społecznego nastawienia do problemu przemocy w wychowaniu starano się rozpoznać preferencje rodziców na temat działań, jakie ich zdaniem wobec rodziców stosujących przemoc powinny być podejmowane.

Zebrane dane obrazują mało optymistyczny obraz na temat świadomości rodziców co do istnienia w Polsce zakazu kar cielesnych (ryc. 10). Wiedzę o funkcjonowaniu w Polsce prawa zakazującego kar cielesnych ma w zasadzie jedynie nieco więcej niż co trzeci rodzic (odpowiedzi "zdecydowanie tak") - 35\%. Poza poziomem świadomości prawa zakazującego kar cielesnych określono także nastawienie rodziców do zakazu - ich ocenę co do jego funkcjonalności (ryc. 11). W tym wypadku większość badanych (57\%) pozy- 


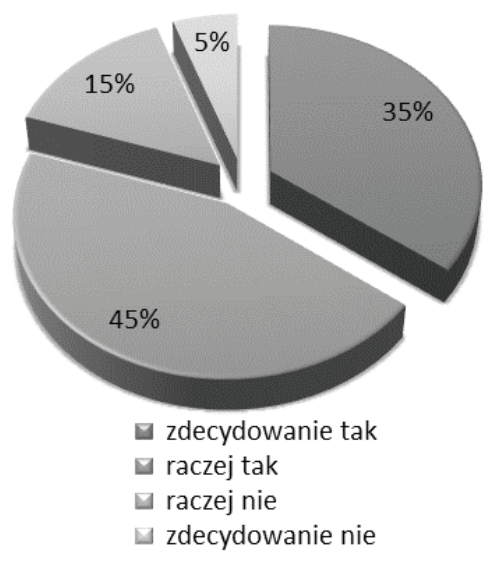

Ryc. 10. „Bicie dziecka jest niezgodne z polskim prawem" $(\mathrm{N}=273)$

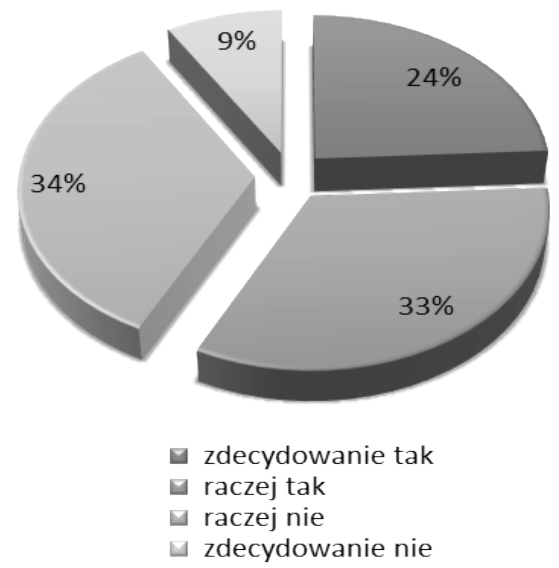

Ryc. 11. Czy Pana/Pani zdaniem wprowadzenie w Polsce całkowitego zakazu bicia dzieci jest słuszne, może przynieść pozytywne skutki - rodzice $(\mathrm{N}=273)$

tywnie ocenia sam zakaz (niezależnie czy wie o jego istnieniu czy nie), jednak zdecydowaną aprobatę zakazu wyraża już jedynie co czwarty rodzic. Ten tak naprawdę mało satysfakcjonujący obraz świadomości rodziców o prawnej ochronie dzieci przed przemocą wyraźnie skłania do refleksji nad potrzebą edukacji na temat istnienia i sensu istnienia zakazu, na temat jego właściwego rozumienia i funkcji, którą przecież nie jest bynajmniej kryminalizacja zachowań, ale edukacyjno-normotwórczy sens.

W ramach rozpoznania społecznego nastawienia do działań wobec sytuacji przemocy $\mathrm{w}$ wychowaniu, analizie poddano zarówno nastawienie rodziców do ingerowania $\mathrm{w}$ tego typu przypadki, jak i ich preferencje co do charakteru działań, jakie powinny być zastosowane w ramach interwencji.

W pierwszym aspekcie badania ujawniły raczej duże przyzwolenie rodziców na ingerencję w sytuacje stosowania kar cielesnych (69\%). Warto jednak zwrócić uwagę, że jedynie co trzeci rodzic w sposób zdecydowany uważał, iż postępowanie $\mathrm{z}$ dzieckiem nie jest wyłącznie prywatną sprawą rodziców (ryc. 12).

Co do charakteru działań jakie należy podejmować wobec rodziców bijących dzieci, preferencje rodziców wyraźnie nominują działania nadzorcze, pomocowe i edukacyjne nad różnymi restrykcjami (ryc. 13).

Najwyższą rangę $\mathrm{w}$ tych preferencjach uzyskały takie działania, jak nadzór kuratora oraz pomoc rodzicom w radzeniu sobie ze stresem, a także ich edukacja w dziedzinie pozytywnych metod oddziaływania na dziecko. Minimalne wskazania dotyczyły natomiast pozbawiania wolności, czy odbierania 


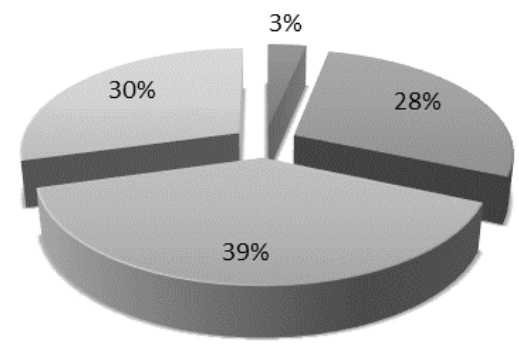

$\square$ zdecydowanie tak $\square$ raczej tak $\square$ raczej nie $\square$ zdecydowanie nie

Ryc. 12. Sposób postępowania rodziców z dzieckiem, w tym posługiwanie się karami fizycznymi, jest wyłącznie ich prywatną sprawą? $(\mathrm{N}=273)$

nie wiem/ trudno powiedzieć powinno się ich edukować w zakresie pozytywnych metod wychowania

powinno się im pomagać lepiej radzić sobie ze stresem i panować nad sobą

powinno się ich przymusowo leczyć (przymusowa terapia)

powinno się ich nadzorować przez kuratora

powinno się im odbierać dzieci i umieszczać je w rodzinach zastępczych

powinno się ich zamykać w więzieniu

żadnych działań, to ich prywatna sprawa

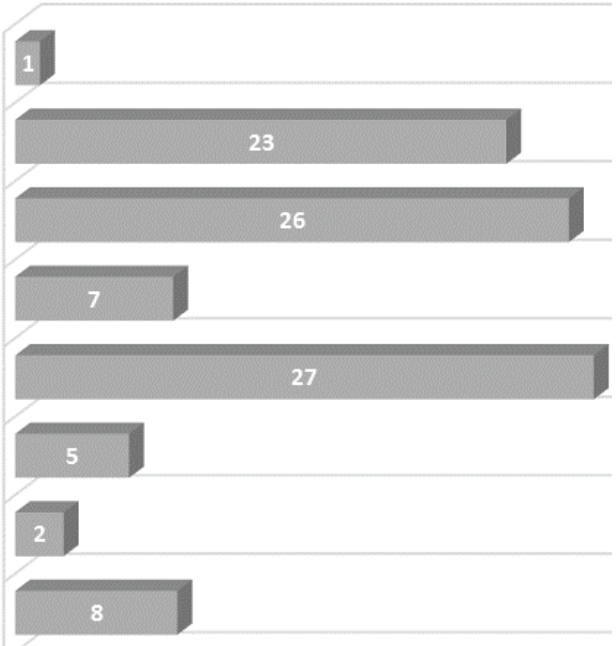

Ryc. 13. Jakie działanie powinno się przede wszystkim podejmować wobec rodziców, którzy biją swoje dzieci? $(\mathrm{N}=273)$

rodzicom dzieci. Ten profil wskazań wydaje się być częściowo efektem silnej jednak kulturowej normy dotyczącej znacznej autonomii rodziny i jej względnej nienaruszalności, choć z drugiej strony można też zauważyć, że jedynie $8 \%$ badanych wykazało negatywną postawę wobec jakiejkolwiek interwencji. Jak więc widać, rodzice generalnie wykazują przyzwolenie na ingerowanie 
$\mathrm{w}$ sytuacje przemocy $\mathrm{w}$ wychowaniu, ale rodzaj tej ingerencji powinien ich zdaniem opierać się bardziej na nadzorze, edukacji i przekonywaniu rodziców oraz pomaganiu im, niż na stosowaniu wobec nich surowych kar. Podobnie jeśli zapytać, co ich zdaniem mogłoby spowodować, że rodzice mniej stosowaliby kary cielesne w wychowaniu (ryc. 14).

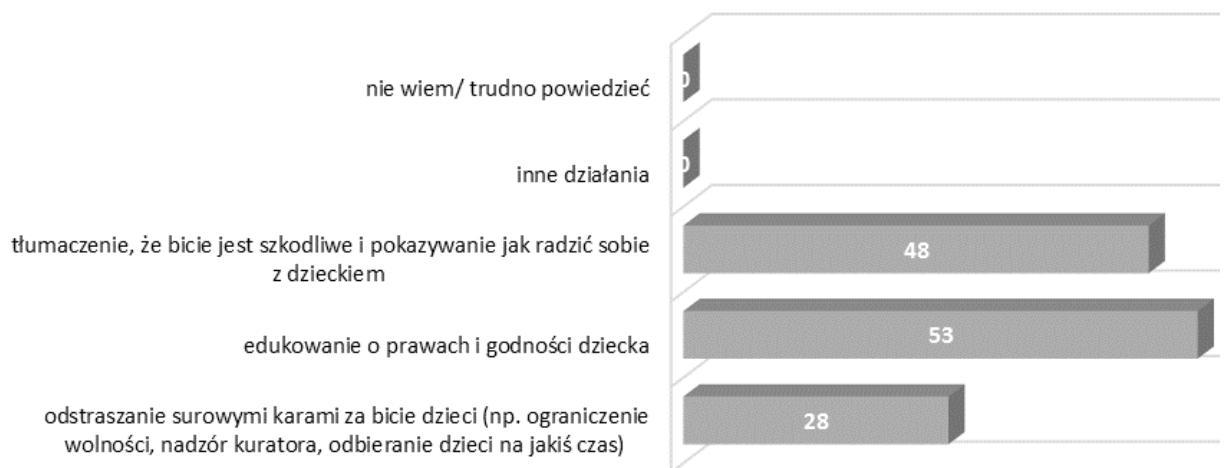

Ryc. 14. Co Pani/Pana zdaniem mogłoby spowodować, że rodzice mniej stosowaliby kary cielesne wobec dzieci? $(\mathrm{N}=273)$

Widać wówczas, podobnie jak w przypadku proponowanych działań wobec rodziców bijących dzieci, zdecydowaną przewagę preferencji działań edukacyjnych nad odstraszaniem poważnymi karami.

\section{Podsumowanie}

Przedstawiony w perspektywie kilku wskaźników obraz postaw rodziców dotyczących przemocy w wychowaniu można zdecydowanie określić jako niekorzystny. Ukazane różne wskaźniki aprobaty zachowań przemocy i stosowania bicia jako metody wychowawczej należy uznać za wysokie i ryzykowne w kontekście występowania samego zjawiska kar cielesnych. Analizy korelacyjne dokonywane zarówno w poprzednich edycjach badań w ramach monitoringu Rzecznika Praw Dziecka, jak i w obecnej z 2017 roku pokazują, że na poziomie istotnym statystycznie rodzice aprobujący kary cielesne częściej faktycznie wykorzystują takie sposoby w praktyce wychowawczej. Badacze problematyki przemocy wobec dzieci podkreślają, że istnieje wyraźny związek pomiędzy aprobatą „lekkich” kar cielesnych (klapsów) oraz stosowaniem ich w praktyce a występowaniem form prze- 
mocy zagrażających zdrowiu i życiu dziecka, ryzykiem pojawiania się form określanych już jednoznacznie jako znęcanie się ${ }^{20}$. Uważa się też, że odkryte związki pomiędzy stosowaniem klapsów a poważnymi formami znęcania się nad dzieckiem wskazują na wysoce prawdopodobny scenariusz, gdzie zmniejszanie akceptacji i używania klapsów będzie owocował zmniejszeniem się liczby przypadków poważnego znęcania się nad dzieckiem ${ }^{21}$. Tego typu konkluzje skłaniają do wyrażenia jako podstawowej rekomendacji zwiększenia zaangażowania różnych podmiotów społecznych - państwowych i obywatelskich - w działania w możliwie szerokich i efektywnych programach oraz środkach, które będą eliminowały jakąkolwiek aprobatę kar cielesnych, nawet w tak zwanej "łagodnej” postaci i w efekcie ich występowanie. Wachlarz działań, jakie mogą do tego prowadzić jest szeroki. Wyraźnie wskazuje się tu na efektywność, obok wprowadzenia zakazu kar cielesnych, między innymi kampanii społecznych ${ }^{22}$, ale też innych działań na różnych poziomach prewencji i poziomach ryzyka stosowania przemocy $\mathrm{w}$ wychowaniu ${ }^{23}$, czyli w sferze prewencji uniwersalnej oraz w obszarach podwyższonego ryzyka ze względu na występowanie $w$ rodzinie, w jej historii i obecnej sytuacji facylitatorów stosowania kar cielesnych. Zdecydowanie należy także postulować wypracowanie spójnej polityki państwa, która w różnych obszarach społecznych, takich jak edukacja, pomoc i wsparcie rodzin, zdrowie psychiczne i ogólne, a nawet zatrudnienie i polityka pracy, będzie promowała rozwiązania, które minimalizują ryzyko działania czynników sprzyjających stosowaniu kar cielesnych oraz innych zachowań przemocy wobec dzieci. Realizację takiego podejścia umożliwia wypracowanie krajowej strategii ochrony dzieci przed wszelką przemocą.

Przemoc w wychowaniu jest najczęściej doświadczaną formą przemocy przez dzieci na całym świecie, daleko wyprzedzającą pod względem częstości występowania inne postaci, jak wykorzystywanie seksualne, czy choćby przemoc rówieśnicza. Szacunki w tej kwestii mówią w skali globu o liczbie znacząco ponad miliarda dzieci do 14. roku życia, które na co dzień doświad-

20 A.J. Zolotor i in., Corporal punishment and physical abuse: Population-based trends for three-to-11-year-old children in the United States, Child Abuse Review, 2011, 20, s. 57-66; E. Gershoff, Spanking and child development, s. 133-137; J.E. Durrant, R. Ensom, Corporal punishment of children: Lessons from 20 years of research, Canadian Medical Association Journal, 2012, 184, s. 1373-1377; J.E. Durrant i in., Punitive violence against children in Canada [CECW information sheet \#41E], Toronto 2006; S.J. Lee i in., Parental spanking and subsequent risk for child aggression in father-involved families of youngchildren? Children and Youth Services Review, 2013, 35(9), s. 1476-1485.

${ }^{21}$ T. Affifi i in., Spanking and adult mental health impairment.

22 J.E. Lansford $\mathrm{i}$ in., Change over time in parents' beliefs about and reported use of corporal punishment in eight countries with and without legal bans, Child Abuse \& Neglect, 2017, 71, s. 44-55.

23 E.T. Gershoff, S.J. Leeb, J.E. Durrant, Promising intervention strategies to reduce parents' use of physical punishment, Child Abuse \& Neglect, 2017, 71, s. 9-23. 
czają przemocowych praktyk wychowawczych ${ }^{24}$. Przemoc w wychowaniu nie stanowi „specjalności” niektórych tylko społeczeństw, jakkolwiek poziom jej występowania jest na świecie różny. Jak pokazują to niedawno opublikowane raporty, najniższy poziom odnotowywany jest $\mathrm{w}$ państwach rozwiniętych, a najwyższy w krajach Afryki oraz w Azji ${ }^{25}$. Oznacza to, że ponad połowa całej populacji dzieci wyrasta w doświadczaniu krzywdy, poniżenia, bólu, lęku, wykorzystania, zagrożenia. Zakres występowania problemu oraz dramatyzm jego konsekwencji spowodowały, że po raz pierwszy w historii międzynarodowa społeczność zdecydowała się umieścić przemoc wobec dzieci wśród pilnych problemów świata, koniecznych do rozwiązania w działaniach globalnych do 2030 roku. Likwidacja przemocy wobec dzieci, w tym w wychowaniu została umieszczona w Celach Zrównoważonego Rozwoju (Sustainable developmental Goals. Agenda 2030), wśród 17 wskazanych w nich obszarów działań, jako cel 16.2. ${ }^{26}$ Dla zrealizowania tej wizji powołano specjalną agendę Global Partnership to End Violence Against Children (Globalne Partnerstwo na rzecz Zakończenia Przemocy wobec Dzieci). Jako platforma działań międzynarodowych opiera się ona na trzech fundamentalnych zasadach: prawa do równej dla każdego ochrony przed przemocą bez względu na wiek, skoncentrowania na dziecku prawach dziecka i jego rozwoju, oraz uniwersalności oznaczającej, że działania eliminacji przemocy powinny być prowadzone we wszystkich bez wyjątku krajach świata. Jak zauważa wielu ekspertów ${ }^{27}$, jest to oczywiście wyzwanie dość monumentalne, biorąc pod uwagę powszechność występowania problemu oraz ogromne zróżnicowanie ekonomicznych i społecznych kontekstów, w jakich żyją dzieci na całym świecie. Ale jednocześnie, biorąc pod uwagę odkryty w badaniach ogrom destrukcji powodowanych przez kary cielesne, koszty społeczne wynikające z negatywnych konsekwencji rozwojowych, koszty związane $\mathrm{z}$ angażowaniem pomocy $\mathrm{w}$ dziedzinie zdrowia psychicznego, sektora sprawiedliwości, specjalnych działań edukacyjnych i kosztów medycznych - jak wyliczają niektóre źródła ${ }^{28}$ - to gra, co podkreślają eksperci,

${ }^{24}$ J. Durrant, Parents' views of the relevance, s. 523-531; Know Violence in Childhood (2017), Ending Violence in Childhood.

${ }^{25}$ Know Violence in Childhood (2017), Ending Violence in Childhood; Know Violence in Childhood, New Delhi 2017, India; Hidden in Plain sight. A statistical analysis of violence against children; zob. też: Annual report of the Special Representative of the Secretary-General on Violence against Children; A familiar face. Violence in the life of children and adolescents, UNICEF, New York 2017; Child is a child. Protecting children on the move from violence, abuse and exploitation, UNICEF, 2017; Towards a world free from violence. Global Survey; Investing in children: the European child maltreatment prevention action plan 2015-2020, WHO, 2014.

${ }^{26}$ http://www.unic.un.org.pl/files/164/Agenda\%202030_pl_2016_ostateczna.pdf [dostęp: 08.11.2017].

${ }^{27} \mathrm{~J}$. Durrant $\mathrm{i}$ in., Parents' views of the relevance.

${ }^{28}$ S. Fang i in., The economic burden of child maltreatment in the United States and implications for prevention, Child Abuse \& Neglect, 2012, 36, s. 156-165; Know Violence in Childhood (2017), Ending Violence in Childhood. 
„warta świeczki” bez względu na koszty i zakres koniecznych działań29. Właśnie taki sposób widzenia warto upowszechniać również w naszym kraju.

\section{BIBLIOGRAFIA}

A familiar face. Violence in the life of children and adolescents, UNICEF, New York 2017.

Afifi T.O. i in., Spanking and adult mental health impairment: The case for designation of spanking as an adverse childhood experience, Child Abuse and Neglect, 2017, 71.

Annual report of the Special Representative of the Secretary-General on Violence against Children, August 2017, http://srsg.violenceagainstchildren.org/http://www.srsg.un.org/, A familiar face. Violence in the life of children and adolescents, UNICEF New York 2017.

Child is a child. Protecting children on the move from violence, abuse and exploitation, UNICEF, 2017.

Durrant J.E., Trocmé N., Fallon B.M.C., Black T., Knoke D., Punitive violence against children in Canada [CECW information sheet \#41E], Toronto 2006.

Durrant J.E., Ensom R., Corporal punishment of children: Lessons from 20 years of research, Canadian Medical Association Journal, 2012, 184.

Durrant J., Plateau D.P., Ateah C.A., Holden G.W., Barker L.A., Stewart-Tufescu A., Jones A.D., Ly G., Ahmed R., Parents' views of the relevance of a violence prevention program in high, medium, and low human development contexts, International Journal of Behavioral Development, 2017, 41(4).

Fang S., Brown D.S., Florence S.C., Mercy J.A., The economic burden of child maltreatment in the United States and implications for prevention, Child Abuse \& Neglect, 2012, 36.

Ferguson C.J., Spanking, corporal punishment and negative longterm outcomes: A meta-analytic review of longitudinal studies, Clinical Psychology Review, 2013, 33.

Gershoff E.T., Corporal punishment by parents and associated child behaviors and experiences: A meta-analytic and theoretical review, Psychological Bulletin, 2002, 128.

Gershoff E.T., Spanking and child development: We know enough now to stop hitting our children, Child Development Perspectives, 2013, 7(3), s. 133-137. http://dx.doi.org/10.1111/ cdep.12038

Gershoff E.T., Grogan-Kaylor A., Lansford J.E., Chang L., Zelli A., Deater-Deckard K., Dodge K.A., Parent Discipline Practices in an International Sample: Associations With Child Behaviors and Moderation by Perceived Normativeness, Child Development, 2010, 81, 2.

Gershoff E.T., Ansari A., Purtell K.M., Sexton H.R., Changes in parents' spanking and reading as mechanisms for Head Start impacts on children, Journal of Family Psychology, 2016 Advance online publication, http://dx.doi.org/10.1037/fam0000172.

Gershoff E.T., Grogan-Kaylor A., Spanking and Child Outcomes: Old Controversies and New Meta-Analyses, Journal of Family Psychology, 2016.

Gershoff E.T., Leeb S.J., Durrant J.E., Promising intervention strategies to reduce parents' use of physical punishment, Child Abuse \& Neglect, 2017, 71.

Glaser D., The effects of maltreatment on the developing brain, The Link, 2000, 16, 2.

Hidden in Plain sight. A statistical analysis of violence against children, UNICEF, New York September 2014.

http:/ / brpd.gov.pl/aktualnosci-ksiazki-informatory-poradniki/polacy-wobec-bicia-dzieci-raport-z-badan-2013

\footnotetext{
${ }^{29}$ J. Durrant i in., Parents' views of the relevance.
} 
http:/ / brpd.gov.pl/ksiazki-informatory-poradniki/dzieci-ofiary-przemocy-w-rodzinie-raport-rzecznika-praw-dziecka

http://www.unic.un.org.pl/files/164/Agenda\%202030_pl_2016_ostateczna.pdf [dostęp: 08.11.2017].

Informacja o działalności Rzecznika Praw dziecka z kolejnych lat 2012-2016, http:/ / brpd.gov. $\mathrm{pl} /$ sprawozdania-z-dzialalnosci

Investing in children: the European child maltreatment prevention action plan 2015-2020, WHO, 2014.

Jarosz E., Polacy wobec bicia dzieci. Raport z badań 2013 dostępnych na stronie RPD, http:// brpd.gov.pl/ksiazki-informatory-poradniki/przemoc-w-wychowaniu-miedzy-prawnym-zakazem-spoleczna-akceptacja

Jarosz E., Przemoc w wychowaniu. Między prawnym zakazem a społeczna akceptacja, BRPD, Warszawa 2015.

Jarosz E., Przemoc w wychowaniu - czas z tym skończyć. Raport Rzecznika Praw Dziecka 2017, http://brpd.gov.pl/sites/default/files/przemoc_w_wychowaniu_raport_2017_0.pdf

Jarosz E., Nowak A., Dzieci ofiary przemocy w rodzinie. Raport Rzecznika Praw Dziecka, BRPD, Warszawa 2012.

Know Violence in Childhood, Ending Violence in Childhood. Global Report 2017.

Know Violence in Childhood, New Delhi 2017, India.

Lansford J.E., Cappa C., Putnick D.L., Bornstein M.H., Deater-Deckard K., Bradley R.H., Change over time in parents' beliefs about and reported use of corporal punishment in eight countries with and without legal bans, Child Abuse \& Neglect, 2017, 71.

Larzelere R.E., Kuhn B.R., Comparing child outcomes of physical punishment and alternative disciplinary tactics: A metaanalysis, Clinical Child and Family Psychology Review, 2005, 8, s. 1-37, http://dx.doi.org/10.1007/s10567-005-2340-z.

Lee S.J., Taylor C.A., Altschul I., Rice J.C., Parental spanking and subsequent risk for child aggression in father-involved families of youngchildren? Children and Youth Services Review, 2013, 35(9).

Paolucci E.O., Violato C., A meta-analysis of the published research on the affective, cognitive, and behavioral effects of corporal punishment, The Journal of Psychology, 2004, 138, s. 197-221, http:/ / dx.doi.org/10.3200/JRLP.138.3.197-222.

Pinheiro P.S., World report on violence against children, UN, Lizbona 2006, www.violencestudy.int.

Romano E., Bell T., Norian R., Corporal punishment :examining Attitudes toward the law and factors influencing attitude change, Journal of Family Violence, 2013, 28.

Strauss M., Paschall M.J., Corporal Punishment by mothers and development of children's cognitive ability: a longitudinal study of two nationally representative age cohorts, Journal of Aggression, Maltreatment \& Trauma, 2009, 18(5).

Teicher M., Wounds that time won't heals. The neurobiology of child abuse, Cerebrum, 2000, 4.

The Global Initiative to End Corporal Punishment: http://www.endcorporalpunishment. org/

Tomoda A., Suzuki H., Rabi K., Sheu Yi-Shin, Polcari A., Teicher M.H., Reduced Prefrontal Cortical Gray Matter Volume in Young Adults Exposed to Harsh Corporal Punishment, Neuroimage, 2009 Aug; 47(2).

Towards a world free from violence. Global Survey on violence against children, SRSG on Violence against children, New York 2013.

Zolotor A.J., Theodore A.D., Runyan D.K., Chang J.J., Laskey A.L., Corporal punishment and physical abuse: Population-based trends for three-to-11-year-old children in the United States, Child Abuse Review, 2011, 20. 
